\title{
STRATEGI PENYULUH BAHASA BALI DALAM MENINGKATKAN KETERAMPILAN BERBAHASA BALI PADA SISWA SEKOLAH DASAR DI DESA BESTALA BULELENG
}

\author{
Ketut Sidang Partayasa ${ }^{1}$; Ni Nengah Selasih ${ }^{2}$; I Ketut Sudarsana ${ }^{3}$ \\ Program Studi Pendidikan Bahasa Bali, Fakultas Dharma Acarya, \\ Universitas Hindu Negeri I Gusti Bagus Sugriwa Denpasar \\ Email: tudpartha13@gmail.com¹; nghselasih@gmail.com² \\ iketutsudarsana@uhnsugriwa.ac.id ${ }^{3}$
}
Diterima tanggal 4 Januari 2021, diseleksi tanggal 6 Februari 2021, dan disetujui tanggal 27 Februari 2021

\begin{abstract}
Balinese was one of the local languages that needed to be preserved. To preserve them requires the planting of understanding that starts with children. The Balinese language lesson got into the local content, so the Balinese study was short. Given matter does not fit the field of possession. The Balinese textbook was also very scant, and the teacher was a class teacher rather than a field teacher. It is to be the student of sd Bestala. Students in the possession of language materials, the characters and literature of Bali are not at maximum. On the basis of this, the Bali language education program with the Balinese learning group provides an additional Balinese lesson outside school hours. In general, the aim of the study is to learn Balinese will be able to improve the Balinese ability of Bestala elementary students, silirite district, buleleng district. Specifically assessed: 1. The upgrade of the grade school student Balinese language skills at Bestala village, 2. The process of learning Balinese in meningthe Balinese language skills at Bestala village, and 3. The implication of the Balinese skills on elementary students in Bestala village. As for the theories used in this study are structural functional theories, constructive theories and behavioristic.
\end{abstract}

Key words: Strategy, Balinese language, Balinese learning group.

\begin{abstract}
ABSTRAK
Bahasa Bali merupakan salah satu bahasa daerah yang perlu dilestarikan. Untuk melestarikannya diperlukan penanaman pemahaman yang dimulai dari anakanak. Pelajaran bahasa Bali masuk ke dalam muatan lokal, sehingga jam pelajaran bahasa Bali menjadi sedikit. Materi yang diberikan tidak sesuai dengan bidang yang dimiliki. Buku penunjang pelajaran bahasa Bali juga sangat minim dan guru pengajar adalah guru kelas bukan guru bidang studi. Fenomena tersebut dialami oleh siswa SD Bestala. Siswa dalam penguasaan materi bahasa, aksara dan sastra
\end{abstract}


Bali menjadi belum maksimal. Berdasarkan hal tersebut kedatangan penyuluh bahasa Bali dengan program kelompok belajar bahasa Bali memberikan tambahan pelajaran bahasa Bali di luar jam sekolah. Secara umum, tujuan penelitian ini adalah melalui kelompok belajar bahasa Bali akan mampu meningkatkan kemampuan berbahasa Bali pada siswa SD Bestala, Kecamatan Seririt, Kabupaten Buleleng. Secara khusus mengkaji: 1. Strategi yang dilakukan dalam meningkatakan keterampilan berbahasa Bali Siswa SD di Desa Bestala, 2. Proses kelompok belajar bahasa Bali dalam meningkatakan keterampilan berbahasa Bali pada Siswa SD di Desa Bestala, dan 3. Implikasi keterampilan berbahasa Bali pada siswa SD di Desa Bestala. Adapun teori yang digunakan dalam penelitian ini adalah Teori Fungsional Struktural, Teori Konstrutivistik dan Behavioristik.

Kata kunci: Strategi, Penyuluh bahasa Bali, kelompok belajar bahasa Bali.

\section{PENDAHULUAN}

Bahasa Bali merupakan salah satu sarana yang digunakan dalam berkomunikasi. Bahasa Bali adalah salah satu bahasa daerah yang patut di jaga dan di lestarikan keberadaannya. Arus Globalisasi sebagai ancaman yang menyebabkan pengguna bahasa Bali semakin sedikit, lebih banyak masyarakat Bali menggunakan bahasa Internasional. Untuk itu sangat penting memberikan pemblajaran bahasa Bali sejak dini. Selain itu, masih banyak masyarakat disaat berkomunikasi menggunakan bahasa Internasional dengan tujuan komunikasi yang terjadi lebih komunikatif atau mudah dipahami. Hal tersebut merupakan keadaan bahasa Bali ketika digunakan dalam berkomunikasi. Hal tersebut, tidak hanya terjadi dalam komunikasi ranah keluarga saja, namun terjadi juga dalam komunikasi masyarakat umum. Seharusnya bahasa Bali merupakan bahasa daerah yang penting dalam komunikasi di Bali yang perlu dilestarikan. Untuk itu, sangat penting menanamkan bahasa Bali mulai dari tingkat dasar. Peran orang tua, keluarga, lingkungaan, sekolah dan teman sepermainan sangatlah penting.

Pendidikan merupakan salah satu tempat untuk merubah prilaku manusia dalam upaya membentuk prilaku yang dan pemikiran yang baik, hal tersebut merupakan jalan untuk menanamkan bahasa Bali dari dasar. Pelajaran bahasa Bali dijadikan sebagai mata pelajaran muatan lokal yang mengakibatkan jam pelajaran bahasa Bali memiliki jam yang sangat sedikit. Buku penunjang pelajaran bahasa Bali juga sangat sedikit sekali. Bahkan, guru pengajar mata pelajaran bahasa Bali diajarkan oleh guru kelas bukan dari guru bidang studi bahasa Bali. Hal tersebut juga dirasakan oleh siswa SD Bestala dimana siswa belum sepenuhnya memahami bahasa, aksara dan sastra Bali. Berdasarkan hal tersebut terbentuk penyuluh bahasa Bali dengan memberikan pelajaran tambahan bahasa Bali di luar jam sekolah berupa program kelompok belajar bahasa Bali. Kelompok belajar adalah salah satu program belajar bahasa Bali yang dilaksanakan di Bale Banjar, Wantilan dan tempat umum lainnya milik dari desa. Dalam pelaksanaanya bahasa Bali tidak bisa lepas dari bahasa, aksara dan sastra Bali, dan empat keterampilan berbahasa yaitu : keterampilan menyimak (mendengarkan), keterampilan berbicara, keterampilan membaca dan keterampilan menulis.

Keadaan yang terjadi saat ini yaitu kemampuan siswa dalam berbicara khususnya di desa Bestala semakin menurun, hal tersebut disebabkan kurang adanya peran dari lingkungan, masyarakat dan keluarga yang belum sepenuhnya memberikan contoh dalam penggunaan bahasa Bali yang baik dan benar. Hal 
lainnya adalah desa Bestala merupakan salah satu wilayah di Kabupaten Buleleng yang sudah terkenal dengan bahasa kasar meskipun hanya digunakan dalam bahasa pergaulan. Hal tersebut sangat berpengaruh terhadap tata aturan dalam berbahasa Bali. Selain itu, kemampuan membaca dan menulis aksara Bali masih sangat rendah. Keadaan tersebut tidak hanya terjadi pada anak-anak saja tetapi terjadi pada orang-orang dewasa juga. Hal tersebut dapat dilihat ketika siswa bertanya dengan tugas yang diberikan gurunya di sekolah orang tua dan anggota keluarga mengalami kesulitan memberikan jawabnnya.

Untuk itu, peneliti mencari upaya agar mampu menjaga keberadaan bahasa Bali utamanya bahasa Bali yang mengikuti kaidah bahasa yang baik dan benar. Berdasarkan hal tersebut peneliti mengambil sebuah penelitian yang berjudul "Strategi Penyuluh Bahasa Bali Dalam Meningkatkan Kemampuan Berbahasa Bali Pada Siswa SD di Desa Bestala, Kecamatan Seririt, Kabupaten Buleleng". Inti dari penelitian ini adalah melalui kelompok belajar bahasa Bali akan mampu meningkatkan keterampilan dan kemampuan berbahasa Bali pada siswa SD di Desa Bestala, Kecamatan Seririt, Kabupaten Buleleng. Berdasarkan uraian yang menjadi latar belakang tersebut, penulis menjabarkan beberapa permasalahan, yaitu: (1) Apakah strategi yang diterapkan Penyuluh bahasa Bali dalam meningkatakan keterampilan berbahasa Bali Siswa SD di Desa Bestala? (2) Bagaimanakah proses kelompok belajar bahasa Bali dalam meningkatakan keterampilan berbahasa Bali Siswa SD di Desa Bestala?, (3) Bagaimanakah implikasi keterampilan berbahasa Bali pada siswa SD di Desa Bestala?. Sedangkan yang menjadi tujuan dari penelitian ini secara umum yaitu Tujuan umumnya yaitu memberikan pandangan bahwa bahasa Bali sangat penting untuk dijaga melaui sebuah program pengajaran yang dimulai sejak dini agar bahasa Bali tidak punah. Tujuan secara khusus yaitu (1) Untuk mengetahui strategi yang dilakukan dalam meningkatkan keterampilan berbahasa Bali siswa SD di Desa Bestala, (2) Untuk mengetahui proses kelompok belajar bahasa Bali dalam meningkatkan keterampilan berbahasa Bali pada siswa SD di Desa Bestala, (3) Untuk mengetahui implikasi keterampilan berbahasa Bali pada siswa SD di Desa Bestala. Manfaat penelitian kelompok belajar bahasa Bali pada siswa SD di Desa Bestala adalah secara teoretis penelitian ini yang menyediakan pemahaman bagi para pelajar dan para pembaca memberikan pemahaman dan penanaman bahasa Bali dari tingkat anak-anak. Penelitian ini juga bermanfaat sebagai referensi agar dapat memberikan informasi yang dapat dijadikan referensi bagi para akademisi, mahasiswa dan masyarakat Bali untuk penelitian selanjutnya. Adapun manfaat praktis dari penelitian ini adalah (1) Bagi guru bahasa Bali guna memotivasi dalam mengembangkan proses pembelajaran yang dikembangkan, (2) Bagi pembaca penelitian ini diharapkan dapat dijadikan pemecahan jalan keluar dari masalah-masalah yang dihadapi tentang bahasa Bali, (3) Bagi masyarakat Bali dapat dijadikan sesuatu prioritas agar minat bahasa Bali dapat meningkatkan sehingga bahasa Bali yang menjadi kebanggaan masyarakat Bali yang tidak dapat dipindahkan oleh penuturnya.

Penelitian ini mengambil beberapa penelitian terdahulu sebagai kajian pustaka, diantaranya penelitian dari Zulela MS, Reza Rachmadtullah, (2017) yang berjudul "Strategi Guru Meningkatkan Pemahaman Bacaan Melalui Pendekatan SAVI (Somatis Auditori Visual dan Intelektual) pada Siswa Kelas V Sekolah Dasar", Sintaningrum, (2013) dalam penelitiannya yang berjudul "Efektivitas Penggunaan Kelompok Belajar Berbasis Sosiometri Untuk Meningkatkan 
Kemampuan Berbicara Bahasa Prancis Siswa Kelas X SMA N 9 Yogyakarta", Abdullah, (2018) dalam penelitiannya yang berjudul "Upaya Meningkatkan Hasil Belajar Bahasa Indonesia Aspek Menulis dengan Penggunaan Model Kooperatif Learning Tipe STAD”, Fatra, Barasandji \& Efendi, (2016) judul penelitian yang diambil yaitu "Peningkatan Kemampuan Siswa Membaca Permulaan Melalui Strategi Bimbingan Langsung pada Siswa Kelas 1 SD Inpres 2 Lambunu", Murda \& Purwanti, (2017) dalam penelitiannya yang berjudul "Penerapan Strategi Pembelajaran Think Pair Share untuk Meningkatkan Kemampuan Membaca Intensif'. Bahri (2008:30) mengatakan bahwa konsep merupakan sejumlah pembendaharaan makna dari sebuah sasaran yang memiliki kesamaan makna. Gagne (Iskandarwassid \& Dadang Sunendar, 2008: 3) menyataan bahwa kecakapan yang dimiliki dalam diri seseorang untuk berpikir, mencari solusi, dan menentukan tindakan disebut strategi.

Dapat dikatakan dalam proses pembelajaran peserta didik akan mampu menganalisis, mecahkan permasalahan dan mengambil solusi terbaik. Penyuluh bahasa Bali merupakan salah satu pegawai kontrak non PNS yang diangkat oleh Pemerintah Provinsi Bali sebagai penyuluh yang memberikan pemahaman dalam tujuan menjaga bahasa, aksara dan sastra Bali. Penyuluh bahasa Bali di tempatkan pada setiap Desayang ada di seluruh di Bali dengan tujuan memberikan penyuluhan. Kelompok belajar merupakan jalur pendidikan nonformal yang difasilitasi oleh pemerintah untuk siswa yang belajar tidak melalui jalur sekolah, atau bagi siswa yang belajar di sekolah berbasis kurikulum non pemerintah. Segala bentuk kegiatan dilaksanakan diluar ruang kelas dengan memberikan materi-materi yang sesuai dengan apa yang diberikan di sekolah, hanya saja prosesnya lebih mengkhusus ke bidang studi bahasa Bali yang dilaksanakan di luar ruangan kelas seperti : Bale Banjar/ Wantilan dan tempat umum lainnya. Sedangkan bahasa Bali adalah satu diantara bahasa daerah yang beraneka ragam di Indonesia yang masih tumbuh bahkan berkembang dan mempunyai cukup banyak pendukung. Hal tersebut menjadikan alasan bahwa bahasa Bali masih bahasa tersebut memilki peran dan fungsi penting di Bali (Suweta, 2013).

Teori-teori yang digunakan dalam penelitian ini adalah teori fungsional struktural yang digunakan untuk menjelaskan rumusan masalah pertama dan kedua yaitu strategi yang diterapkan Penyuluh bahasa Bali untuk meningkatakan keterampilan berbahasa Bali dan proses kelompok belajar bahasa Bali dalam meningkatakan keterampilan berbahasa Bali pada siswa SD di Desa Bestala. Teori belajar konstruktivisme digunakan untuk menjawab rumusan masalah yang kedua yaitu proses kelompok belajar bahasa Bali pada siswa SD di Desa Bestala. Teori belajar behavioristik merupakan teori yang digunakan untuk menjawab menjawab rumusan masalah yang ketiga yaitu implikasi keterampilan berbahasa Bali pada siswa SD di Desa Bestala tepatnya pada tingkah laku siswa.

Penelitian ini menggunakan penelitian kualitatif karena berdasar pada kejadian atau konversi yang terjadi sedemikian rupa. Tujuannya untuk mengetahui bagaimana cara meningkatkan kemampuan, faktor-faktor yang mempengaruhi, upaya-upaya untuk meningkatkan kemampuan berbahasa Bali dalam kelompok belajar bahasa Bali untuk siswa SD di Desa Bestala, Kecamatan Seririt. Lokasi penelitian diambil di Desa Bestala, Kecamatan Seririt, Kabupaten Buleleng. Jenis datanya dipilah menjadi dua yaitu (1) data kuantitatif jenis data didapat secara langsung, dan (2) data kualitatif merupakan data yang penting namun tidak dalam 
penelitian secara langsung. Sumber data terdiri dari data primer sumber dan sekunder. Data Primer merupakan data pertama yang mencakup siswa Sekolah Dasar Bestala beserta guru pengajar bahasa Bali di sekolah. Data sekunder merupakan kumpulan data yang didapatkan oleh peneliti dari sumber-sumber yang ada. Instrumen penelitian yang digunakan yaitu tehnik pengumpulan data yang sesuai dengan observasi, pedoman wawancara dan studi kepustakaan. Tehnik penentuan informan dengan Purposive sampling yaitu informan dipilih dengan mempertimbangkan tentang masalah yang akan dibahas. Tehnik pengumpulan data dengan menggunakan metode observasi partisipan, sebab peneliti ikut serta dan berperan secara langsung dalam proses dan kegiatan yang dilakukan. Dalam pengumpulan data dilakukan dengan studi kepustakaan, wawancara, dan pencatatan dokumen. Sedangkan teknik analisis data penelitian ini melalui beberapa tahapan yaitu reduksi data, klasifikasi data, penyajian data dan kesimpulan. Untuk tehnik penyajian analisis data dengan penyajian lampiran-lampiran yang dipaparkan secara naratif diiringi data informan, daftar pustaka, surat pernyataan bahwa telah melakukan penelitian pada kelompok belajar Penyuluh bahasa Bali, dan panduan wawancara yang dilengkapi dengan kelengkapan lain yang mendukung penelitian ini.

\section{PEMBAHASAN}

Gambaran umum lokasi penelitian kali ini memaparkan mengenai Sejarah dari Desa Bestala yang menjadi tempat penelitian, letak geografis, keadaan demografi, keadaan sosial budaya, keadaan SD Negeri Bestala dan keadaan kelompok belajar bahasa Bali. Desa Bestala merupakan salah satu Desa yang terletak di Timur Laut, Kecamatan Seririt, Kabupaten Buleleng. Kata Bestala terdiri dari dua suku kata yaitu "basta" berarti diikat atau dijerat dan "mala" berarti keluar lidahnya. Dalam sejarah perjalanannya kata mala menjadi "la". Penggabungan kata basta dan la menjadi "Bastala" yang mempunyai arti kena jerat keluar lidahnya, kemudian menjadilah "Bestala" yang menjadi tempat tinggal sebagai kenangkenangan cara berburu. Desa Bestala adalah salah satu dari 21 Desa/Kelurahan di Kecamatan Seririt yang terdiri 2 (dua) Banjar Dinas yaitu Banjar Dinas Taman, dan Banjar Dinas Sari, serta 1 (satu) Desa Adat yaitu Desa Adat Bestala. Adapun batasbatas wilayah Desa Bestala adalah sebagai berikut : sebelah utara adalah Desa Mayong, sebelah Timur adalah Desa Munduk Bestala, sebelah Selatan adalah Desa Munduk Bestala dan Desa Mayong, dan sebelah Barat adalah Desa Mayong dan Desa Gunung Sari. Keadaan wilayah Desa Bestala merupakan wilayah bebukitan sehingga mempengaruhi siswa dalam mengikuti kegiatan kelompok belajar bahasa Bali. Selain itu, masyarakat di Desa Bestala. Penduduk Desa Bestala sebagian besar merupakan petani dan memiliki tamatan SD.

SD Negeri Bestala di bangun pada tahun 1964. Jumlah guru yang mengajar sebanyak 7 orang dimana 5 orang sebagai guru muatan lokal. 2 orang guru sebagai pegawai honor dan 3 orang sebagai PNS. 1 orang sebagai pengajar mata pelajaran Agama Hindu yang berstatus PNS, 1 orang sebagai tenaga administrasi dan 1 orang sebagai pegawai Perpustakaan. Kelompok belajar bahasa Bali diawali dengan kemunculan penyuluh bahasa Bali pada tahun 2016. Program kelompok belajar dilaksanakan dengan tujuan untuk memberikan pelajaran bahasa Bali di luar jam sekolah sebab pelajaran bahasa Bali diajarkan oleh guru kelas bukan dari guru bidang studi bahasa Bali. Selain itu, jam plajaran bahasa Bali sangat sedikit di 
tambah lagi dengan buku penunjang bahasa Bali sangat minim. Hal itu membuat siswa belum memahami bahkan bosan dengan pelajaran bahasa Bali. Selain itu, siswa SD sangat jarang mendengarkan satua-satua Bali yang memiliki nilai kearifan lokal tinggi dan kurang menguasai sor singgih bahasa Bali. Tujuan kelompok belajar untuk memberikan pemahaman siswa mulai dari tingkat dasar. Kegiatan dilaksanakan di sore hari dan tempat pelaksanaan di Wantilan/Bale Banjar, Kantor Kepala Desa dan tempat umum lainnya. Materi yang diberikan tidak lepas dari ketrampilan bahasa yaitu : menyimak, berbicara, membaca dan menulis dengan tetap berpatokan pada bahasa, aksara dan sastra Bali. Namun dalam proses masih mengalami kendala seperti : tempat, peserta dan sarana dalam kegiatan.

Keadaan kelompok belajar bahasa Bali di Desa Bestala diawali denga koordinasi dengan Kepala Desa, Klian Adata Bestala berserta prajuru, tokoh masyarakat, kepala sekolah dan guru pengajar di SD Bestala. Tujuan dari koordinasi adalah untuk menyampaikan proses program kelompok belajar bahasa Bali tersebut. Program kelompok belajar sangat di dukung oleh pemerintah desa adat dan dinas terbukti dengan disediakan sarana dan prasarana kegiatan. Pada proses awal peserta masih sedikit namun seiring berjalan waktu semakin banyak yang mengikuti kegiatan kelompok belajar.

Tata cara penyuluh bahasa Bali dalam meningkatkan kemampuan berbahasa Bali salah satunya melalui kelompok belajar bahasa Bali. Dalam kelompok belajar siswa diberikan program pembelajaran bahasa Bali, pembinaan bahasa Bali dan outbond bahasa Bali. Kelompok belajar khusus diberikan untuk siswa SD dengan tujuan memberikan pemahaman mulai dari tingkat dasar. Pada proses kelompok belajar bahasa Bali tentunya memiliki tahapan-tahapan materi yang diberikan. Pada pembelajaran bahasa Bali di awali dengan pengumpulan buku-buku penunjang kegiatan. Sinergi dari pemerintah dinas Desa Bestala berupa anggaran dan biaya yang digunakan dalam menjalankan program berupa: papan tulis, spidol, buku saku aksara Bali, dan lain sebagainya. Semua itu diberikan dalam anggaran pelaksanaan pembangunan Desa sub bidang pendidikan. Selain itu, terdapat juga pembinaan bahasa Bali untuk memberikan kematangan berbahasa Bali serta perekrutan siswa secara rinci dan pembentukan bibit-bibit dalam lomba nantinya. Pembinaan seiring dengan program dari pemerintah mulai dari tingkat Kecamatan, Kabupaten hingga Provinsi yang secara berkala mengadakan lomba-lomba, festival, dan lainnya yang menyangkut bahasa, aksara dan sastra Bali dengan tujuan tetap melestarikan bahasa, aksara dan sastra Bali. Adapun pembinaan yang diberikan berupa pembinaan menulis aksara Bali, membaca aksara Bali, matembang/makidung, masatua, pidato dan lain sebagainya. Selanjutnya, berupa program outbond belajar sambil bermain. Kegiatan ini menjadi kegiatan favorit siswa sebab siswa disamping mendapat materi juga dapat bermain, bernyanyi, dan bermain tebak-tebakan tentang bahasa Bali bersama teman-temannya. Kegiatan dilaksanakan di Wantilan Desa Bestala dengan tujuan siswa dapat bergembira, santai dalam belajar namun mendapatkan pelajaran.

Proses pembelajaran bahasa Bali pada kelompok belajar bahasa Bali SD Bestala yaitu tidak lepas dari bahasa, aksara dan sastra Bali dan empat keterampilan bahasa. Keterampilan menyimak dengan mendengarkan satua Bali. Prosesnya yaitu siswa memasuki ruangan mempersiapakan alat tulis dan tempat duduk masingmasing, kemudian dilanjutkan dengan absensi, proses tersebut berlangsung 15 menit. Siswa menyimak/mendengarkan pengajar bercerita, cerita yang diambil 
salah satunya cerita yang berjudul "I Belog". Pengajar mendongeng kepada siswa berlangsung selama 30 menit hingga selesai. Dari dongeng yang didengarkan siswa ditugaskan untuk memahami cerita yang dingarkan dengan mencari siapa saja tokoh dalam dongeng, karakter dari tokoh, mencari pesan yang disampaikan dalam cerita yang didengarkan selama 30 menit. Siswa ditugaskan untuk menceritakan kembali isi cerita yang telah didengarkan selama 30 menit. Waktu selama 10 menit dipakai untuk pemberian tugas yang akan dikerjakan dirumah. Sisa waktu 5 menit digunakan siswa untuk berkumpul, berdoa dan mengucapkan salam sebelum menuju rumah masing-masing. Dilanjutkan dengan keterampilan berbicara yaitu : Siswa memasuki ruangan mempersiapakan alat tulis dan menempati meja yang ada berlaku selama 15 menit. Pada awal pelajaran pengajar memberikan contoh cara memperkenalkan diri beserta anggota keluaraga dengan bahasa Bali.

Siswa menyimak untuk memahami apa yang dijelaskan oleh pengajar. Selama 30 menit siswa satu per satu ditunjuk untuk memeperkenalkan diri beserta anggota keluarganya. Setelah semua selesai siswa diberikan materi nama-nama anggota tubuh dengan bahasa bali sesuai dengan sor singgih selama 30 menit. Selama 10 menit dipakai untuk memberikan pekerjaan rumah yang dibahas pada pertemuan berikutnya. Sisa waktu 5 menit untuk siswa berkumpul berdoa dan mengucapkan salam sebelum menuju rumah masing-masing. Untuk keterampilan menulis yang diberikan yaitu menulis aksara Bali. Prosesnya yaitu : siswa memasuki tempat kegiatan, mengucapkan salam dan absensi, kegiatan berlangsung 15 menit. Pada awal pelajaran pengajar memberikan contoh bentuk aksara Bali dasar dengan media LCD dan papan tulis. Selama 30 menit siswa diberikan kesempatan untuk mencatat dan menanyakan apa yang belum dipahami. Kemudian dilanjutkan dengan materi mengenal angka Bali beserta hitungan Bali selama 30 menit. Waktu 10 menit dengan meberikan pekerjaan rumah dan 5 menit siswa berkumpul untuk berdoa sebelum menuju rumah masaing-masing. Keterampilan membaca diberikan membaca aksara Bali. Pada prosesnya siswa memasuki tempat kegiatan dengan mengucapkan salam dan absensi berlangsung 15 menit. Pada awal pelajaran pengajar memberikan contoh membaca teks beraksara Bali dasar dengan media LCD, selembaran kertas, buku LKS ataupun papan tulis selama 30 menit. Pada awal pelajaran pengajar memberikan contoh membaca teks beraksara Bali dasar dengan media LCD, selembaran kertas, buku LKS ataupun papan tulis selama 30 menit. 10 menit untuk memberikan pekerjaan rumah dan 5 menit untuk berkumpul, berdoa dan pulang menuju rumah masing-masing.

Dalam pembinaan lebih menitik beratkan pada kegiatan persiapan lombalomba yang akan diikuti baik melalui sekolah ataupun secara umum. Materi yang diberikan bidang bahasa, aksara dan sastra Bali. Pembinaan yang diberikan berupa : pembinaan menulis aksara Bali, matembang/mapupuh, masatua Bali, berpidato, sambutan dengan lebih menekannkan penggunaan tingkatan-tingkatan bahasa Bali. Dalam pembinaan aksara Bali dilakukan dengan tata cara menulis aksara Bali dari tingkat dasar sampai pada tahap pemantapan. Pada pembinaan sastra menitik beratkan pada pembelajaran matembang/kidung dari tingkat dasar sampai siswa mampu menguasai kidung/tembang yang diberikan. Selain itu, diberikan tata cara masatua Bali.

Outbond bahasa Bali merupakan salah satu media pembelajaran yang diterapkan dalam kelompok belajar. Outbond diberikan dengan tujuan memberikan pelajaran bahasa Bali diiringi belajar sambil bermain. Tempat pelaksanaan outbond 
di Wantilan Pura Taman sebab memiliki wilayah yang luas sehingga siswa lebih leluasa diajak bermain sambil belajar bahasa Bali. Proses pelaksanaan outbond yaitu dengan mengumpulkan siswa kelas 3,4,5 dan 6 yang merupakan peserta kelompok belajar kemudian dibagi menjadi menjadi beberapa kelompok. Masingmasing kelompok saling memberikan pertanyaan berupa tebak-tebakan dalam bahasa Bali. Materi yang digunakan yaitu Basita Paribasa Bali. Pelaksanaan belajar sambil bermain juga dilaksanakan dengan diawali pemebrian materi berupa tembang-tembang yang dijadikan sebagai yel-yel dalam permainan. proses belajar sambil bermain ini mirip dengan dolanan. Tembang-tembang yang diberikan itu diambil dari sebuah buku kumpulan tembang rare karangan bapak Made Taro. Selain itu, siswa juga diberikan bermain puzzle aksara Bali, tebak-tebakan mencari nama buah, binatang dan benda yang diawali dengan huruf A-Z.

Implikasi kemampuan berbahasa Bali siswa SD di Desa Bestala sesuai dengan bidang bahasa, aksara, sastra Bali dan prilaku siswa. Bidang bahasa Bali terlihat dari prestasi siswa yang mampu mengikuti lomba pidato antar Desa seKecamatan Seririt dalam acara Festival Seririt Budaya tahun 2017. Bidang Aksara Bali salah satu siswa mampu meraih juara I lomba menulis aksara Bali tingkat SD se-Kecamatan Seririt dalam Festival Seririt Budaya tahun 2017 dan juara 3 lomba lomba menulis aksara Bali tingkat SD se-Kecamatan Seririt dalam Festival Seririt Budaya tahun 2018. Bidang Sastra Bali siswa peserta kelompok belajar bahasa Bali sudah mengetahui dan mampu menguasai beberapa tembang/kidung yang terlihat pada persembahyangan di sore hari, di sekolah miwah tampil ring stasiun radio tepatnya RRI Singaraja. Selain itu juga siswa mengalami perubahan tingkah laku yang terlihat dari tata cara berbicara dengan orang tua, keluaraga, guru dan temantemannya dengan menggunakan sor singgih bahasa Bali. Bahkan setiap kegiatan kelompok belajar siswa diwajibkan berpakaian adat sehingga siswa rajin berpakaian adat.

\section{SIMPULAN}

Berdasarkan hasil penelitian kualitatif yang dilaksanakan pada SD di Desa Bestala tentang "Strategi Penyuluh Bahasa Bali Dalam Meningkatkan Keterampilan Berbahasa Bali Pada Siswa SD di Desa Bestala, Kecamatan Seririt Kabupaten Buleleng" yaitu : (1) Strategi yang dilakukan penyuluh bahasa Bali untuk meningkatkan kemampuan bahasa Bali pada siswa SD di Desa Bestala melalui kelompok belajar bahasa Bali. Kelompok belajar bahasa Bali menitik beratkan pada: pembelajaran, pembinaan dan Outbond bahasa Bali. (2) Proses pembelajaran materi yang diberikan yaitu bidang bahasa, aksara, sastra dan belajar sambil bermain. Bidang bahasa seperti : sor singgih bahasa Bali, perkenalan diri, dan percakapan dalam bahasa Bali. Bidang Aksara Bali materi yang diberikan berupa belajar menulis dari dasar dan membaca teks beraksara Bali. Pada bidang sastra materi diberikan berupa belajar matembang Bali Sekar Rare, Sekar Alit dan Kidung. Tidak hanya pembelajaran saja, siswa juga diberikan pembinaan bahasa Bali. (3) Impilkasi dari kelompok belajar bahasa Bali pada siswa SD Bestala yaitu : siswa mampu meraih juara I dan juara III dalam lomba menulis aksara Bali. Mampu menguasai beberapa Tembang/Kidung yang digunakan dalam upacara persembahyangan di masyarakat maupun disekolah. Tampil dalam acara yang diselenggarakan atas kerjasama antara penyuluh bahasa Bali Kabupaten Buleleng dengan station Radio RRI Singaraja. Siswa mengikuti lomba yang lainnya sudah 
diikuti yaitu lomba pidarta tingkat Kecamatan, dan adanya perubahaan sikap dan prilaku siswa dari segi cara berbicara, berpakaian adat Bali serta senang dengan pelajaran bahasa Bali.

Berdasarkan hasil penelitian tentunya masih menemukan beberapa kendala dalam proses penelitian, sehingga peneliti mengajukan saran yaitu: dapat dijadikan pedoman, motivasi dalam mengembangkan proses dan inovasi pembelajaran untuk guru bahasa Bali. Adanya penelitian lanjutan dan lebih dalam lagi tentang strategi pembelajaran bahasa Bali terutama kelompok belajar bahasa Bali. Sebagai prioritas untuk meningkatkan minat belajar bahasa Bali.

\section{DAFTAR PUSTAKA}

Abdullah, N. (2018). Upaya Meningkatkan Hasil Belajar Bahasa Indonesia Aspek Menulis Dengan Penggunaan Model kooperatif Learning Tipe STAD. Jurnal Pendidikan Tambusai, 2(2), 217-225.

Adibah, I. Z. (2017). Struktural Fungsional Robert K. Merton: Aplikasinya Dalam Kehidupan Keluarga. INSPIRASI: Jurnal Kajian dan Penelitian Pendidikan Islam, 1(2), 171-184.

Alahi, M. E. E., \& Mukhopadhyay, S. C. (2019). Literature Review. Smart Sensors, Measurement and Instrumentation, 35(2009), 7-41. https://doi.org/10.1007/978-3-030-20095-4_2

Alwi, H., Dardjowidjojo, S., Lapoliwa, H., \& Moeliono, A. M. (2019). Tata bahasa baku bahasa Indonesia.

Anshori, M., \& Iswati, S. (2019). Metodologi Penelitian Kuantitatif: Edisi 1. Airlangga University Press.

Ardial, H. B. (2005). Pedoman Penulisan Karya Ilmiah (Proposal, Skripsi, dan Tesis). Jakarta: Kencana.

Bestala, Desa. Profil Desa Bestala. Kabupaten Buleleng : 2019.

Bestala, Desa. Rencana Pembangunan Jangka Menengah. Kabupaten Buleleng : 2020.

Damayanti, E. (2019). Analisis Kesiapan Belajar Siswa Menjelang Ujian Akhir Pada Peserta Didik Kelas IX Mts Ainus Syamsi ( Studi Kasus Menurut Teori Thorndike ) The Analysis Of Students' Study Readiness Towards Final Examination Of Ninth Grade Students Of Mts Ainus Syamsi ( A. 1(1), 29-41.

Danoebroto, S. W. (2015). Teori Belajar Konstruktivis. P4TK Matematika, 2, 191198. Retrieved from http://idealmathedu.p4tkmatematika.org/wpcontent/uploads/2016/01/7_Sri-Wulandari-D.pdf

Devianty, R. (2017). Bahasa Sebagai Cermin Kebudayaan Rina. Jurnal Tarbiyah, $X x i V(1), 226-245$.

Djaka. (2011). Kamus Lengkap Bahasa Indonesia Masa Kini. Surakarta: Pustaka Mandiri.

Fatra, S., Barasandji, S., \& Efendi, E. (2016). Peningkatan Kemampuan Siswa Membaca Permulaan Melalui Strategi Bimbingan Langsung Pada Siswa Kelas 1 SD Inpres 2 Lambunu. Jurnal Kreatif Tadulako, 4(5). Retrieved from 
https://www.neliti.com/id/publications/120492/peningkatan-kemampuansiswa-membaca-permulaan-melalui-strategi-bimbingan-langsung

Hasanah, U. (2017). Strategi guru kelas dalam meningkatkan kemampuan membaca permulaan pada siswa kelas 1 di Sekolah Dasar 'Aisyiyah Kamila Dinoyo Malang (Doctoral dissertation, Universitas Islam Negeri Maulana Malik Ibrahim).

Hendryadi. (2014). Metode Pengumpulan Data. 1-5. Retrieved from www.teorionline.net

Hikma, N. (1990). Aspek Psikologis Tokoh Utama Dalam Novel Sepatu Dahlan Karya Khrisna Pabichara (Kajian Psikologi Humanistik Abraham Maslow). Jurnal Humanika, 39(1), 283-286. https://doi.org/10.1016/S00078506(07)61054-3

http://eprints.undip.ac.id/40650/3/BAB_III.pdf Diakses pukul 20.30 wita, tanggal $19 / 1 / 2020$.

http://Bestala-buleleng.Desa.id/index.php/first/kategori/19 Diakses pukul 20.00 wita, tanggal 31/10/2020.

https://dapo.kemdikbud.go.id/sekolah/79F8E34098DD2FDC966F Diakses pukul 18.30 wita tanggal $27 / 11 / 2020$.

Indonesia, T. R. K. B. (2008). Kamus Bahasa Indonesia. Jakarta: Pusat Bahasa Departemen Pendidikan Nasional, 725.

I Putu Pande Suargita, I. K. S. (2011). Upaya Masyarakat Daerah Pariwisata Candidasa Kabupaten Karangasem dalam Mempertahankan Keberadaan Bahasa Bali. Institut Hindu Dharma Negeri Denpasar, 11-19.

James, B., Gustaf, G., \& Erik, E. (n.d.). Mempersiapkan Sekolah Minggu Dewasa ( Pra Remaja ) Generasi Milenial Kristen Dengan Menggunakan Teori Kebutuhan Abraham Maslow. 1-14.

Madekhan, M. (2019). Posisi Dan Fungsi Teori Dalam Penelitian Kualitatif. Jurnal Reforma, 7(2), 62. https://doi.org/10.30736/rfma.v7i2.78

Mahmudi, M. (2016). Penerapan Teori Behavioristik Dalam Pembelajaran Bahasa Arab ( Kajian Terhadap Pemikiran Bf . Skinner ). Prosiding Konferensi Nasional Bahasa Arab II, 429-435.

Marzali, A. (2014). Struktural-fungsionalisme. Antropologi Indonesia.

Maunah, B. (2016). Pendidikan dalam Perspektif Struktural Fungsional. CENDEKIA: Journal of Education and Teaching, 10(2), 159178.

Mukhtar. (2013). Metode Penelitian Deskriptif. Metode Penelitian Deskriptif, 125.

Murda, N., \& Purwanti, P. D. (2017). Penerapan Strategi Pembelajaran Think Pair Shareuntuk Meningkatkan Kemampuan Membaca Intensif Siswa. International Journal of Elementary Education, 1(1), 11. https://doi.org/10.23887/ijee.v1i1.11434 
Purnomo, S. (2014). Krisis Karakter Dalam Perspektif Teori Struktural Fungsional. Jurnal Pembangunan Pendidikan: Fondasi Dan Aplikasi, 2(1), 72-81. https://doi.org/https://doi.org/10.21831/jppfa.v2i1.2619

Rahardjo, M. (2011). Metode Pengumpulan data penelitian kualitatif.

Rahmawati, E. R. (2015). Implementasi Penddikan Nonformal Di Desa Sikayu Kecamatan Buayan Kabupaten Kebumen. Skripsi.

Robert, B., \& Brown, E. B. (2004). Bahasa Bali sebagai Simbol Identitas Manusia Bali I Made Suastra Universitas Udayana Abstraksi. (1), 1-14.

Sekaran, U., \& Bougie, R. (2017). Metode Pengumpulan Data: Kuesioner. Metode Penelitian Untuk Bisnis: Pendekatan Pengembangan-Keahlian, (01), 170.

Sila, I. M. (2016). Revitalisasi Manajemen Pasraman Dalam Menumbuhkan Sikap Revolusi Mental Secara Berkelanjutan Pada Pasraman Di Desa Puhu Kacamatan Payangan. Jurnal Kajian Pendidikan Widya Accarya FKIP Universitas Dwijendra, (2085), 1-21.

Silvia Citra Linda dan Hadiyanto. (2019). Jurnal basicedu. Jurnal Basicedu, 3(2), $524-532$.

Sintaningrum, M. S. (2013). Efektivitas Penggunaan Kelompok Belajar Berbasis Sosiometri untuk Meningkatkan Kemampuan Berbicara Bahasa Prancis Siswa Kelas XI SMA N 9 Yogyakarta . Skripsi .

Suargita, I. P. P., \& Sudarsana, I. K. (2019). Upaya Masyarakat Daerah Pariwisata Candidasa Kabupaten Karangasem dalam Mempertahankan Keberadaan Bahasa Bali. Pariwisata Budaya: Jurnal Ilmiah Agama Dan Budaya, 2(2), 11-19.Gulo, W. (2002). Metodologi Penelitian. Jakarta: Grasindo.

Suastra, I. M. (2004). Bahasa Bali Sebagai Simbol Identitas Manusia Bali. Universitas Udayana Abstraksi. Universitas Udayana, (1), 1-14.

Subakti, Y. R. (2010). Paradigma Pembelajaran Sejarah Berbasis Konstruktivisme. 24(1), 1-23.

Sueca, I. N. (2013). Eksistensialisme Budaya Dan Sikap Adaptif Penyuluh Agama Hindu dalam Pembinaan Pendidikan di Pasraman Lombok Barat .

Sutarjo Adisusilo, J. (2016). Konstruktivisme Dalam Pembelajaran. Edunomic, 4(1), 1-25. Retrieved from http://idealmathedu.p4tkmatematika.org/wpcontent/uploads/2016/01/7_Sri-Wulandari-D.pdf

Suweta, I. M. (2013). Revitalisasi Istilah Tumbuh-Tumbuhan Langka dalam Pengajaran Bahasa Bali, Sebagai Upaya Pelestarian Lingkungan Hidup (Kajian Ekolinguistik). Bumi Lestari Journal of Environment, 13(1).

Waseso, H. P. (2018). Kurikulum 2013 Dalam Prespektif Teori Pembelajaran Konstruktivisme. Ta'lim, 1(1), 59-72.

Zulela MS, Reza Rachmadtullah, Y. E. Y. S. (2017). Strategi Guru Meningkatkan Pemahaman Bacaan Melalui Pendekatan SAVI Siswa Kelas Sekolah Dasar. JPD : Jurnal Pendidikan Dasar, 8(1), 159-168. https://doi.org/doi.org/10.21009/JPD.081.13 